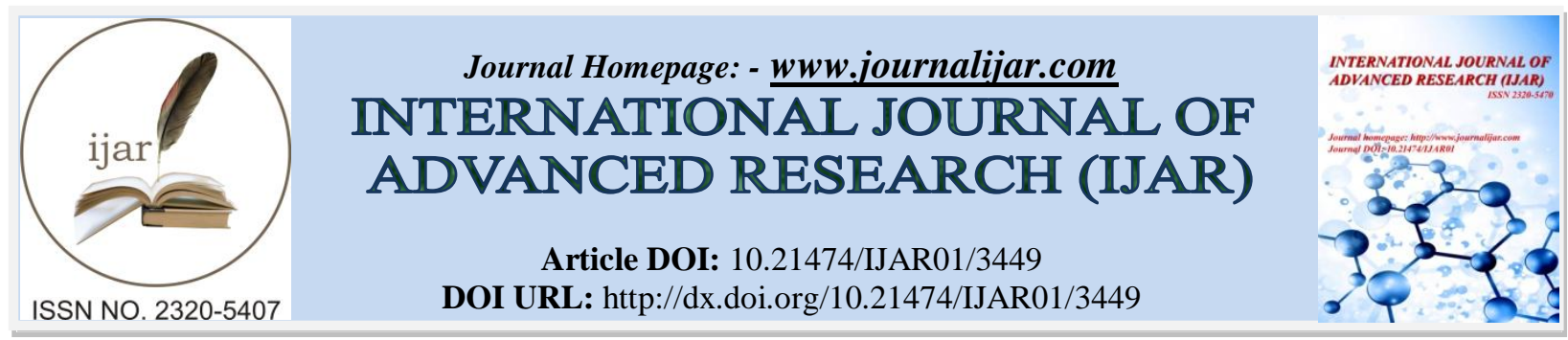

RESEARCH ARTICLE

\title{
INTRAPERITONEAL BUPIVACAINE FOR POSTOPERATIVE PAIN RELIEF AFTER LAPAROSCOPIC CHOLECYSTECTOMY
}

Dr. Gurmeet Singh, Dr. Athar Parvez, Dr. Digamber Chaubey, Dr. Ajay Verma and Dr. K. B. Jain.

\section{Manuscript Info}

Manuscript History

Received: 26 December 2016

Final Accepted: 16 January 2017

Published: February 2017

Key words:-

Laproscopic cholecystectomy,

Bupivacaine

\begin{abstract}
Pain is defined as "an un-pleasant sensory and emotional experience associated with actual or potential tissue damage".Laparoscopic cholecystectomy is now an established form of treatment for patients with symptomatic gallstones. Recent studies have shown that patients may experience considerable pain after laparoscopic cholecystectomy. The various methods used with variable success are NSAID'S, infiltration of wound with local anesthetics and intermittent intramuscular narcotics. In Laproscopic Cholecystectomy after removal of gall bladder from the abdominal cavity using an endobag the position of the patient was made supine and $0.25 \%$ of $10 \mathrm{ml}$ bupivacaine was instilled in the gall bladder fossa under direct laparoscopic control in Group A patients while Group B patients did not receive any such solution.Group A showed less intensity of pain with time duration as compared to Group B. A descriptive analysis of the VAS pain scores was in table 1. Statistically significant stepwise decrease in pain score at $4 \mathrm{hrs}, 8 \mathrm{hrs}, 12 \mathrm{hrs}$ and $24 \mathrm{hrs}$ were found in Group A and B. Intraperitoneal bupivacaine for laparoscopic cholecystectomy in a dose of $10 \mathrm{ml}$ of $0.25 \%$ rather than using a higher dose reduces pain in the initial postoperative period and also in first 24 hrs, it is easy to administer with no adverse effects and may become a routine practice for this procedure.
\end{abstract}

Copy Right, IJAR, 2017,. All rights reserved.

\section{Introduction:-}

Pain is defined as "an un-pleasant sensory andemotional experience associated with actual or potential tissue damage". ${ }^{1}$ From this definition it isclear that pain is a multi-modal entity and is the endresult ofdiverse input conditioned by the individual'sconstitution and prior experience. ${ }^{2}$ Postoperativepainremains one of the most prevalent problems inhealthcare today and pain control is a topic of current interest. ${ }^{3}$

Laparoscopic cholecystectomy is now an establishedform of treatment for patients with symptomatic gallstones.Although thought to result in less postoperative pain,recent studies have shown that patients may experienceconsiderable pain after laparoscopic cholecystectomy ${ }^{4,5}$. Thevarious methods used with variable success are NSAID'S ${ }^{6}$, infiltration of wound with local anesthetics ${ }^{7}$ andintermittent intramuscular narcotics ${ }^{8}$. Narchi et al observed reduction in postoperativeshoulder pain in minor gynecological surgery afterintraperitoneal instillation of local anesthetics ${ }^{9}$.With the possibility that a similar beneficial effectmight be achieved in laparoscopic cholecystectomy anumber of studies were carried out with variableresults ${ }^{4,5,10,11}$.Keeping in view the variable results obtained byBupivacaine is usedto control postoperative pain after laparoscopicprocedures. In many studies 
$0.125 \%$ to $0.5 \%$ bupivacaine is used intraperitoneally ${ }^{12}$ or in thewound ${ }^{13}$ but with conflicting result. While in others, the use of intraperitoneal bupivacaine is found safe and effective. This techniquefor relieving postoperative pain iseasy to perform in patients undergoing laparoscopic cholecystectomy. ${ }^{14-20}$

This study was conducted to see the efficacy ofinstillation of $10 \mathrm{ml} 0.25 \%$ bupivacaine intraperitoneally afterremoval of gall bladder in gallbladder fossa for post-operativepain relief after laparoscopic cholecystectomyand then to apply the same for the future laparoscopic cholecystectomies.

\section{Material \& Methods:-}

The study was conducted in Department of General surgery, in a multispeciality hospital atLucknow from August 2013 till June 2014.Sampling technique is non-probability purposive.After the approval of local ethical committee a study was done on 120 patients undergoing Laparoscopic Cholecystectomy. Written and informed consent was taken from all the patients. The method of using Visual Analogue Scale was explained to thepatients pre operatively. Same surgical team performed all the surgical procedures. Laparoscopic cholecystectomy was completed with thestandard four-port technique and carbon dioxidepnemoperitoneum.Patients with mucocele, empyema and patients in whom drain was placed, were excluded from the study.After removal of gall bladder from the abdominal cavity using an endobag the position of the patient was made supine and $0.25 \%$ of $10 \mathrm{ml}$ bupivacaine was instilled in the gall bladder fossa under direct laparoscopic control in Group A patients while Group B patients did not receive any such solution.

Simultaneously, each group was assessed forintensity of pain at rest through Visual Analogue Scale at 4,8,12 and 24 hrs after surgery. All the patients weredischarged 24 hours post operatively.The consumption of analgesics was also recorded. Allthe assessments were performed by a single observer (post graduate on duty) who was blinded to the group allocations.Data regarding meanpain score was collected through structured performa. Data was analyzed at SPSS version 15.0.Baseline data (intensity of pain) was first analyzed through VAS after 4 hrs after surgery. Theintermediate readings were at 8 and $12 \mathrm{hrs}$ and final assessment at $24 \mathrm{hrs}$ after surgery.Pairedt test were applied to assess the data.The results were concluded significant when $\mathrm{p}$-value less than $0.05(\mathrm{p}<0.05)$.

\section{Results:-}

A total of 120 patients planned for elective cholecystectomy were included in thisstudy divided in two groups.All were adult males and females. The gender distribution betweentwo groups showed non-significant difference (Fishers Exact Test $=0.325$ with $\mathrm{P}=0.16$ ). Overall male to female ratio was 1:3.7 Mean age(years) of Group A was $45.04 \pm 13.85$ ranging from 25 to 70 years while in Group B it was44.86 \pm 15.07 ranged from 20 to 65 years .The difference in age between two groups was found statistically insignificant $(\mathrm{t}=0.068, \mathrm{P}=0.95)$. Weight $(\mathrm{kgs})$ between two groups was found staticallyinsignificant $(\mathrm{t}=0.24, \mathrm{P}=0.81)$.In Group A mean weight was $57.87 \pm 8.65 \mathrm{kgs}$ and in Group B it was $58.23 \pm 7.56 \mathrm{kgs}$. ASA Status I was more frequent in bothgroups as compared to Status II.Status I were 59.2\% whereas Status II were 40.8\% in Group A.In Group B, ASA Status I were69.4\% and Status II was 30.6\%. Thereis no statistical difference in frequency distribution of two groups in ASA status (Fishers Exact Test $=0.40, \mathrm{P}=0.25$ ).

Group A showed less intensity of pain with time duration as compared to Group B. A descriptive analysis of the VAS pain scores was in table 1. Statistically significant stepwise decrease in pain scoreat $4 \mathrm{hrs}, 8 \mathrm{hrs}, 12 \mathrm{hrs}$ and 24 hrs were found in Group A and B as shown in figure \& table below.

\begin{tabular}{|c|c|c|c|c|c|c|}
\hline Variables & Group & $\mathbf{N}$ & Mean & SD & t-value & p-value \\
\hline Age & $\begin{array}{l}\text { Group - A } \\
\text { Group - B }\end{array}$ & $\begin{array}{l}60 \\
60\end{array}$ & $\begin{array}{l}45.04 \\
44.86\end{array}$ & $\begin{array}{l}13.85 \\
15.07\end{array}$ & $\mathrm{t}=0.068$ & $0.95^{*}$ \\
\hline Weight (kg) & $\begin{array}{l}\text { Group - A } \\
\text { Group - B }\end{array}$ & $\begin{array}{l}60 \\
60\end{array}$ & $\begin{array}{l}57.87 \\
58.23\end{array}$ & $\begin{array}{l}8.65 \\
7.56\end{array}$ & $t=0.24$ & $0.81^{*}$ \\
\hline VAS at $4 \mathrm{hrs}$ & $\begin{array}{l}\text { Group - A } \\
\text { Group - B }\end{array}$ & $\begin{array}{l}60 \\
60 \\
\end{array}$ & $\begin{array}{l}2.09 \\
4.98 \\
\end{array}$ & $\begin{array}{l}0.87 \\
0.98 \\
\end{array}$ & $\mathrm{t}=17.0825$ & $0.0001^{\#}$ \\
\hline VAS at $8 \mathrm{hrs}$ & $\begin{array}{l}\text { Group - A } \\
\text { Group - B }\end{array}$ & $\begin{array}{l}60 \\
60\end{array}$ & $\begin{array}{l}1.67 \\
3.56\end{array}$ & $\begin{array}{l}0.57 \\
0.89\end{array}$ & $t=13.8519$ & $0.0001^{\#}$ \\
\hline VAS at 12hrs & $\begin{array}{l}\text { Group - A } \\
\text { Group - B }\end{array}$ & $\begin{array}{l}60 \\
60 \\
\end{array}$ & $\begin{array}{l}0.89 \\
2.88\end{array}$ & $\begin{array}{l}0.34 \\
0.69\end{array}$ & $\mathrm{t}=20.0391$ & $0.0001^{\#}$ \\
\hline VAS at $24 \mathrm{hrs}$ & $\begin{array}{l}\text { Group - A } \\
\text { Group - B }\end{array}$ & $\begin{array}{l}60 \\
60\end{array}$ & $\begin{array}{l}0.22 \\
1.98\end{array}$ & $\begin{array}{l}0.48 \\
0.92\end{array}$ & $\mathrm{t}=13.14$ & $0.0001^{\#}$ \\
\hline
\end{tabular}


*Statistically insignificant \#statistically significant

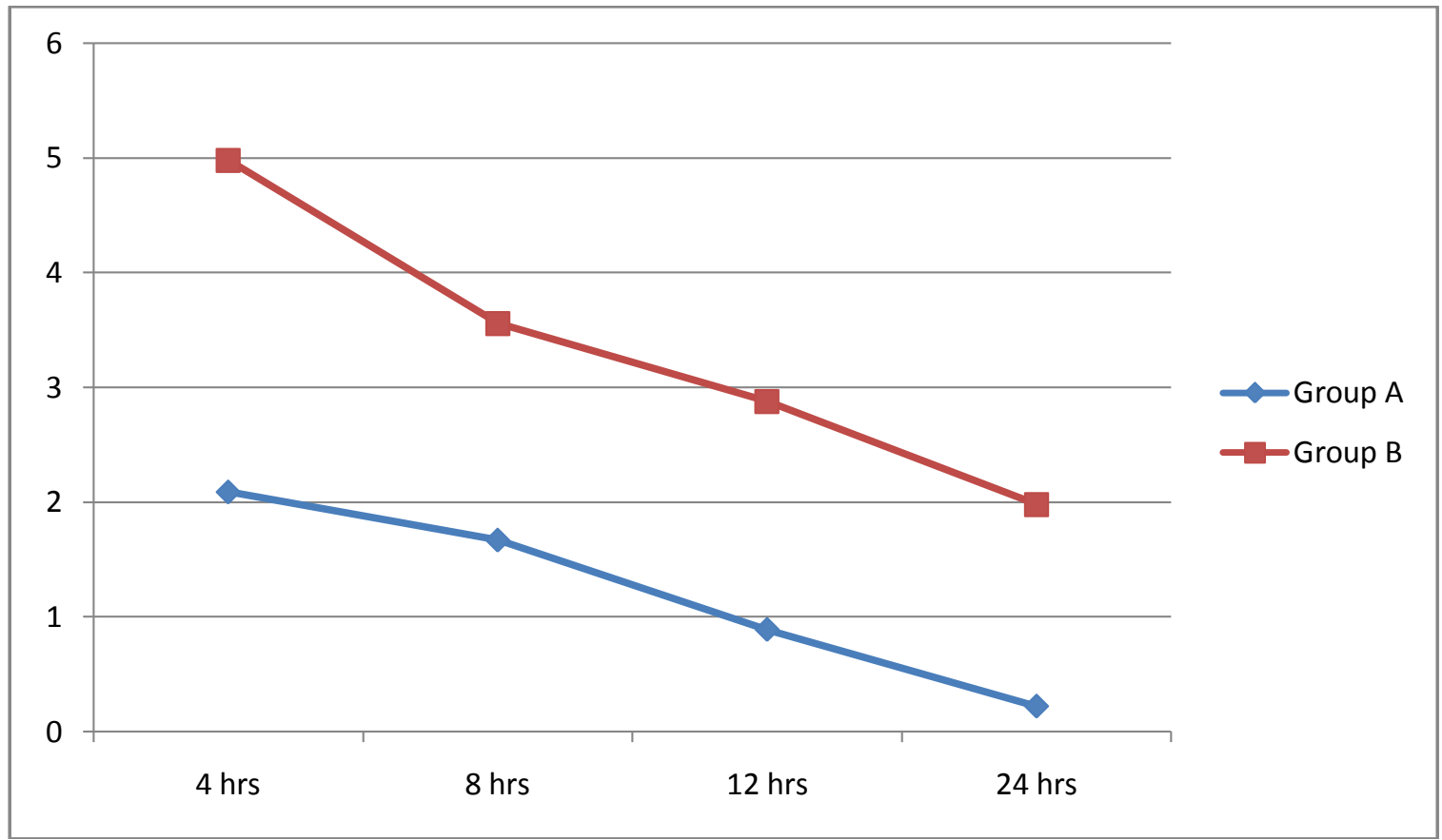

Figure: -A statistically significant difference was seen in VAS after 4,8,12 and 24 hrs of laparoscopic cholecystectomy.

\section{Discussion:-}

Although minimally invasive surgery characterized by reduced pain, it is not painless. Patients undergoing laparoscopic cholecystectomy suffered considerable pain on the day of surgeryfrequently requiring narcotic analgesics. Local infiltration of analgesia had been used successfully in combination with General anesthesia for breast surgery, facial cosmetic operations and body contouring procedures.

In the early post operative period visceral painaccounts for the most of the pain experiencedafter laparoscopic cholecystectomy. ${ }^{5}$ Local anesthetics induced anti nociception by acting on the nerve membranes. These analgesics interventions need to produce a sufficientlydense and long duration of blockade for themto block the transmission of noxious afferent information from the periphery to the spinal cord and brain. ${ }^{6}$

There is little evidence with regard to whichtype of LA is most effective because limited dataare available for drugs other than bupivacaine.Bupivacaine itself (or levobupivacaine) is an excellent choice for intraperitoneal LA because of its long duration of action. The originality of this trial was the instillation of $0.25 \% \quad$ of $10 \mathrm{ml}$ bupivacaneintraperitoneally onlyafter the removal of gall bladder in the gallbladder fossa.At trocar site or incisional site no local anesthetics wasinstilled, as many studies did not support port site local anesthetic infiltration of wound. ${ }^{21,22}$ Clinical studies of intraperitoneal bupivacaine had inconsistent results. Few authors have found a statistically significant difference with the useof localanesthetics ${ }^{10,20,23-25}$ others could notrepeat these results. ${ }^{26,27}$ Furthermore in a few studies that have found a statistically significant difference with the use of bupivacaine, the difference between the average pain scores was lessthan 1 in a scale of $10 .^{23,25}$

Narchi et al found intraperitoneal local anesthetics to be more effective in reducing pain up to 48 hrs postoperatively in patients undergoing diagnostic laparoscopy ${ }^{9}$. Subsequent studies failed to demonstrate the beneficial effect of intraperitoneal instillation of local anesthetics in patients undergoing laparoscopic cholecystectomy ${ }^{4,5,10,12}$.

Utilizing $20 \mathrm{ml}$ of either $0.25 \%$ bupivacaine or $0.5 \%$ lignocaine, Rademaker et al failed to demonstrate any reduction in postoperative pain. ${ }^{4}$ A possible explanation of the failed effect given by them was the small amount of 
local anesthetics used as compared to Narchi et al. Also instillation of local anesthetics in the supine position prevented its flow over the coeliac plexus and phernic nerve endings.

Joriset at studied the characteristics of pain after laparoscopic cholecystectomy and the effect ofintraperitoneal instillation of $80 \mathrm{ml}$ of $0.125 \%$ bupivacaine with adrenaline ${ }^{5}$. They found that visceral pain accounts for the major discomfort experienced in early postoperative period whereas shoulder tip pain becomes the main complaint on the second day. The intensity of shoulder pain in their study was less than the study of Narchi et al probably because of careful emptying of carbon dioxidepneumoperitoneum. The author felt that because ofexistence of several components of pain, its relief will depend on therapy for each of these components. In addition an anatomic intraperitoneal flow directs local anesthetics away from cholecystectomy wound and therefore cannot attain sufficient concentration to block the nociceptive input from abdominal wall incisions. Keeping in view the importance of positioning while instilling the local anesthetic, Scheinin et al administered $100 \mathrm{ml}$ of either 0.15\% plain bupivacaine or with adrenaline in 20 degree head down tilt maintained for $20 \mathrm{~min}^{1{ }^{11}}$ They found no relief of pain after laparoscopic cholecystectomy. The lack of analgesic efficacy can beattributed to the lower concentration of bupivacaine used and more extensive and longer duration of surgery compared to gynecological laparoscopies.

Studies done previously used $20 \mathrm{ml}$ of $0.5 \%$ Bupivacaine had also shown similar results as ours. ${ }^{28,29}$ In our study a statistically significantly low VAS was seen in Group A using $0.25 \%$ of $10 \mathrm{ml}$ Bupivacaine as compared to Group B using no intraperitoneal anesthetic agent instillation.

\section{Conclusion:-}

Intraperitoneal bupivacaine forlaparoscopic cholecystectomy in a dose of $10 \mathrm{ml}$ of $0.25 \%$ rather than using a higher dose reduces pain in the initialpostoperative period and also in first $24 \mathrm{hrs}$, it is easy to administer with noadverse effects and may become a routine practice forthis procedure.

\section{References:-}

1. Merskey H. Pain terms: A list with definitions and notes on usage recommended by the IASP subcommittee on taxonomy. Pain1979;6:249-52.

2. Morely S. Vivid memory for every day pains. Pain 1993; 55:55-62.

3. Alessandri F, Lijoy D, Mistrangelo E et al. Effects of presurgical local infiltration of levobupivicane in the surgical field on post surgical wound pain in laparoscopic gynecological surgery. ActaObstetGynecol Scand 2006; 85:844-9.

4. Rademaker BM, Ringers J, Odoom JA et al. Pulmonary function a stress response after laparoscopic cholecystectomy: comparison with subcostal incision and influence of thoracic epidural anaesthesia. Anesthesia and Analgesia 1992; 75: 381-385.

5. Joris J, Cigarini, I, Legrand $\mathrm{M}$, Jacquet $\mathrm{N}$ et al. Metabolic and respiratory changes after cholecystectomy performed via laparotomy or laparoscopy.Brit J Anaesth 1992; 69: 341-345

6. $\quad$ Lord Mc Coll. Laparoscopic cholecystectomy. Am R collSurgEngl: 1992;74:231

7. Rees BI, Williams HR. Laparoscopic Cholecystectomy the first 155 patients. Am R CollSurg Eng 1992; 74:233-236.

8. Scott AND, Greville AC, Mc Millan L et al.Laparoscopic laser cholecystectomy results of the technique in 210 patients Am R CollSurg; 1992; 74: 237 - 241.

9. Narchi P, Benhamou D, Fernandez H. Intraperitoneal local anaesthetic for shoulder pain after day case laparoscopy. The Lancet 1991; 338: 1569-1570.

10. Chundrigar T, Morris R, Hedges AR et al. Intraperitoneal bupivacaine for effective pain relief after laparoscopic cholecystectomy. Annals R collsurgEngl; 1993;75:437-439.

11. Scheinin B, Kellokiempu I, Lindgren L et al. Effect of intraperitoneal bupivacaine on pain after laparoscopic cholecystectomy. ActaAnaesthesia Scand; 1995;39: 195-198.

12. Pasqualucci A, Angelis VA, Contrado $R$ et al. PreenptiveAnagesiaIntraperitoneal local anaesthetic in laparoscopic cholecystectomy. A randomised, double blind, placebo controlled study. Anesthesiology 1996; 85: $11-20$.

13. Khan SA, Butt K, Chaudhry ZA, S Mushtaq A, Experience with 0.5\% Bupivacaine Pro-peritoneal Bleb.after laparoscopic cholecystectomy - A new Trend in analgesia. Ann King Edward Med Coll. 2000;6(4):359-60.

14. Chundrigar T, Hedges AR, Morris R et al. Intraperitoneal bupivacaine for effective pain relief after laparoscopic cholecystectomy. Ann R CollSurgEngl 1993;75:437-9. 
15. Rademaker BM, Kalkman CJ, Odoom JA, et al. Intraperitoneal local anaesthetics after laparoscopic cholecystectomy: effects on postoperative pain, metabolic responses and lung function. $\mathrm{Br} \mathrm{J}$ Anaesth 1994;72:263-6.

16. Louizos AA, Hadzilia SJ, Leandros E et al. Postoperative pain relief after laparoscopic cholecystectomy.SurgEndosc. 2005;19:1503-6.

17. Verma GR, Lyngdoh TS, Kaman L et al. Placement of $0.5 \%$ bupivacaine soaked surgicel in the gall bladder bed is effective for pain after laparoscopic cholecystectomy. Surg.Endosc.2006;20:1560-4.

18. Karaaslan D, Sivaci RG, Akbulut G et al. Preemptive analgesia in laparoscopic cholecystectomy: a randomized controlled study. Pain Pract. 2006;6:237-41.

19. Tariq GR, Mian MA, Chaudhry IA.Comparision of inrtaperitoneal analgesia with bupivacaine/bupivacaine with ketorolac after laparoscopic cholecystectomy. J Surg Pak 2004;9:9-13.

20. Mraović B, Jurisić T, Kogler-Majeric V et al. Intraperitonealbupivacaine for analgesia aft er laparoscopic cholecystectomy. Acta Anaesthesiol Scand.1997Feb;41(2):193-6.

21. Khan RA ,WaseemN,etal,The effectiveness of intra operative wound infiltration with long acting LocalAnesthetic. J Postgrad Med Inst,Nov-Jan 2002;16(1):26-8.

22. Moiniche $\mathbf{S}$, Jorgensen $\mathrm{H}$, Wetterslev $\mathbf{J}$ et al. Local anesthetic infiltration for postoperative pain relief aft er laparoscopy: a qualitative and quantitative systematic review of intraperitoneal, port-site infiltration and mesosalpinxblock. AnesthAnalg 2000;90:899-912.

23. Szem JW, Hydo L, Barie PS. A double blind evaluation of intraperitoneal bupivacaine vs saline for the reduction of postoperative pain and nausea after laparoscopic cholecystectomy.SurgEndosc. 1996; 10: 44-48.

24. Cunniff e MG, McAnena OJ, Calleary J et al. A prospective randomized trial of intraperitoneal bupivacaine irrigation for management of shoulder-tip pain following laparoscopy. Am J Surg. 1998;176:258-261.

25. Tsimoyiannis EC, Glantzounis G, Lekkas ET, et al. Intraperitoneal normal saline and bupivacaine infusion for reduction of postoperative pain after laparoscopic cholecystectomy.SurgLaparoscEndosc 1998;8:416-20.

26. Aman Z.,QayumAet al . A study of effectiveness of local Bupivacaine infiltration of the wound in reducing the post operative parenteral narcotic analgesic requirement. J Postgrad Med Inst Jan-Mar2004;18(1):7-11.

27. Scheinin, B., Kellokumpu,I., Lindgren, L.et al. Effect of intraperitoneal bupivacaine on pain after laparoscopic cholecystectomy. ActaAnaesthesiologicaScandinavica, 1995, 39:195-198.

28. Bhardwaj N, Sharma V, Chari P.INTRAPERITONEAL BUPIVACAINE INSTILLATION FORPOSTOPERATIVE PAIN RELIEF AFTER LAPAROSCOPICCHOLECYSTECTOMY. Indian journal of anesthesia; 46(1): 49-52.

29. Wasim M, Shafqatullah S M, Subhan A. Role of intraperitoneal bupivacaine in laparoscopicCholecystectomy. Pak J Surg 2014; 30(3):222-226. 